\title{
Politeness and Impoliteness in Javanese Speech Levels
}

\author{
Farida Nuryantiningsih \\ Indonesian Literature \\ Faculty of Humanities \\ Jenderal Soedirman University \\ Indonesia \\ faridanuryanti79@gmail.com
}

\author{
Wiekandini Dyah Pandanwangi \\ Indonesian Literature \\ Faculty of Humanities \\ Jenderal Soedirman University \\ Indonesia \\ wiekandinipandanwangi@gmail.com
}

\begin{abstract}
Linguistic Politeness is the act of a person in speaking which respect others according to the prevailing norm in the society. In Javanese society, a person is categorized as polite speaker when the person can use degree of Javanese speech correctly. The ability of a speaker using the degree of Javanese speech correctly in communication reflects the politeness degree of the speaker's behavior. Otherwise, impoliteness in language is speech act that is normatively considered negative because violating the prevailing social norms in a society. According to Rahardi (2003) impoliteness in language is speech act (1) deliberate carelessness (2) playing the face, (3) harassing positive face, (4) harassing negative face, and (5) removing face. Javanese language is a unique language because there is speech level (undha usuk). Philosophical value of Javanese speech degree teaches Javanese people about a very deep humanity values such as andap asor(being modest), empan papan(adaptable everywhere), respect each other, the recognition of diversity, aja dumeh(don't be arrogant) and tepa seliro(tolerance). Javanese speech degree system shows the importance of politeness custom that intertwines the system of Javanese people relationship. (Soepomo, 1979, p. 59). However, not all Javanese people understand about the Linguistic Politeness. It happens because not all people understand and able to use undha usuk (Speech level) correctly in communication. This research is aimed to analyze the politeness and impoliteness in Javanese speech level.

This research uses qualitative approach by applying descriptive method. Data collection method that is used is observation attentively and conversation method. Meanwhile, data analysis method that is used is pragmatic comparing method with speech partner as its determinant device.
\end{abstract}

Keywords - linguistic politeness; linguistic impoliteness; javanese speech level

\section{INTRODUCTION}

Linguistic Politeness is an act of a person in speaking which respect others according to the prevailing norm in the society. In Javanese society, a person is categorized as polite speaker when the person can use level of Javanese speech correctly. The ability of a speaker using the level of Javanese speech correctly in communication reflects the politeness degree of the speaker's behavior. When communicating with the hearer, a speaker does not only tell the idea or notion using the language that has been understood, but it must pay attention or obey the social norm that has been agreed upon by the speaker's community. This is done in order to make the speaker not be considered as the one who does not know politeness. Speaking by selecting polite diction is one example of respecting each other. Beside the act of respecting other people, speaking politely shows the level of character of a speaker.

Otherwise, impoliteness in language is speech act that is normatively considered negative because violating the prevailing social norms in a society. According to Rahardi (2003) impoliteness in language is speech act (1) deliberate carelessness (2) playing the face, (3) harassing positive face, (4) harassing negative face, and (5) removing face.Impoliteness can be seen from lingual and non-lingual parameter. Lingual parameter is realized into tone, pressure, intonation, or diction. Meanwhile, non-lingual parameter is determined by situation factor and the atmosphere of speech. Politeness and impoliteness of language is pragmatics study because it related to principles how language is used in social context. Pragmatics manages about which one is appropriate to say, how to say it, when it can be said, and how the language that is used can be accepted by other people.(Bowen, 2001)

Javanese language is a language which contains politeness values, friendliness, and respecting. Those values can be seen in the usage variation of Javanese language as a tool of communication. One of the characteristic of Javanese language is there is a speech level system (undha usuk). The values in level of Javanese language speech teaches about humanity values, which are andap asor, empan papan, aja dumeh, and tepa seliro. Speech level system of Javanese language is an important sign of politeness which intertwine 
the relationship system of Javanese people (Soepomo, 1979, p. 59). Nevertheless, not all of Javanese people understand about the Linguistic Politeness. This happens because not all people understand and proficient in using speech level (undha usuk) well in terms of communication.

The discussion about the speech level in Javanese language has been done by several researchers, which are Poedjosoedarmo et al. (1979), Uhlenbeck(1982), Sudaryanto (1989), Purwo (1995), Sasangka (2004), Wibawa (2005), and Wedhawati et al. (2006). From the result of speech level discussion in Javanese language, the researcher concludes that speech act in Javanese language is divided into four, which are ngoko lugu, ngoko alus, karma lugu, and karma alus.

Ngoko lugu is used to communicate between the speaker with the hearer whose kinship is very close or the speaker and the hearer share the same age. Contoh tindak tutur ngoko lugu adalah 'Mas Adi, sesuk kowe sido mulih ora?'. Tuturan di atas adalah tuturan yang diucapkan seorang adik kepada kakaknya.Because having a very close kinship, the speaker uses ngoko lugu with the hearer. Ngoko alus is used to communicate between the speaker whose age is younger than hearer. Besides, ngoko alus is also used by the speaker who is eager to be respected or respect hearer even though they share the same age. Contoh tindak tutur ngoko alus adalah 'Mas, wingi sampeyan sido tuku buku ora?' Tuturan di atas sama maknanya dengan contoh tuturan ngoko lugu. The difference is in ngoko alus, the speaker uses word sampeyan(you) to replace word kowe(you) because speaker is eager to respect hearer.

Meanwhile, bahasa krama, whether it is krama lugu or krama alus is used by the speaker who is always eager to respect the hearer. The speaker assumes that respecting each other need to be preserved so that the language that is used having the level of higher politeness. Yet, there is difference in using krama lugu and krama alus. Krama lugu is usually used by speaker in informal speech, while, krama alus is used in formal speech. Besides, karma lugu is used by speaker with the hearer whose age is same and having close relationship. Meanwhile, krama alus is used by the speaker to hearer whose age is older and there is social gap between speaker and hearer. Contoh tindak tutur krama lugu 'Sampeyan badhe wangsul teng pundi?' Tindak tutur di atas adalah tindak tutur yang diucapkan oleh seorang penutur kepada mitra tutur sebaya untuk menanyakan tujuan kepulangannya. Apabila mitra tutur yang dikenalnya usianya lebih tua, maka penutur menggunakan tindak tutur krama alus menjadi 'Panjenengan badhe kondur wonten pundi?'

Linguistic Politeness can't be separated from language ethics. If the politeness related to language essence so language ethics related to the behavior in using language. If a person is able to speak well, that person will be respected by other person. Speak by using polite language, polite words, and soft voice will make other people being sympathetic and respect the speaker. On the other hand, someone who speaks rudely, impolite and does not pay attention on other person's feeling will tear down the person's self-esteem. Thus, the usage of polite language will show the person's identity. In Javanese language, there is unggah ungguhing basa, kasar alusing rasa and jugar genturing tapa. The term that wishes the alignment of inner and outer life, physical, material and spiritual (Supadjar, 1978, p. 74). In society's interaction, Javanese people is encouraged to follow social rules or suba sita. One of the thing that should be paid attention at having relationship with other people is the usage of the language. The rule in using language in this case is the using of speech act that should be obeyed.

This research is aimed to analyze the politeness and impoliteness of language in speech act of Javanese language. In this research, politeness principal that is used is politeness principal that is proposed by Leech(1983), which are 1) The application of Linguistic Politeness principal. This principal is marked by maximizing pleasure or respecting value, compliment, and sympathy toward other people and minimizing those things toward themselves; 2) Avoidance of taboo words. The word that refers to something disgusting and rude words such as taboo words or unusual words that is used in communication; 3), The usage of euphemism, which is the usage of words having soft meaning; 40 the usage of honorific word which is the usage of respecting words toward other people. Meanwhile, the discussion about impoliteness is based on the impoliteness theory by Culpeper, which are bald on record impoliteness, positive impoliteness, negative impoliteness, mock politeness, and withhold politeness. Besides, impoliteness in Javanese language can happen if 1) the usage of lexicon is not appropriate with the level of speech, 2) the usage of rude words is considered into impolite in Javanese language, 3) cultural and social context can be the cause of impoliteness in Javanese language usage.

\section{RESEARCH METHOD}

This research uses qualitative method by applying descriptive method. Desctiptive method is chosen by researcher because this method can give illustration as accurate as possible about individual, language situation, symptomps or specific groups. Survey research design or go directly to research location to know and directly involved in communication act of javanese language speech level in research location. Data collection method that is used is observation method and conversation method. Observation method has basic technique named tapping technique(Mahsun, 2005, p. 90). Then, this tapping technique is followed by advanced technique which is Involved Conversation Observation technique. In this involved conversation observation technique, the researcher uses tapping by 
participating while observating, participating in conversation, and observating the conversation. In this case, the researcher is involved directly in the dialogue. Then, writing technique is advanced technique that is done by the researcher when applying observation method with those advanced technique mentioned above.

Besides, researcher uses conversation method too. Method of providing data using conversation method is caused by the way that is done in collecting data is conversation between researcher with informant. (Mahsun, 2005, p. 90) In this analysis, it is used pragmatic identity method with deciding tool is hearer. (Sudaryanto, 1993, pp. 13-15). Pragmatics in identity method must be understood by deciding element outside the language (Djaja sudarma, 1993, p. 59). Data analysis using identity pragmatics method is aimed to describe the unity of language in interaction using correct Javanese language speech act between the speaker and hearer in Yogyakarta and Purwokerto area.

\section{DISCUSSION}

\section{A. Linguistic Politeness in Javanese Language Speech Act}

Linguistic Politeness (according to Leech, 1986) must pay attention on four principal. First, application of politeness principal in language. This principal is marked by maximizing pleasure / wisdom, profits, a sense of salute or respect, compliment, compatibility, and sympathy to other and minimizing those things toward themselves. Second, the avoidance of taboo word. In most society, the words that has sex oriented, the word that refers to body organs that is commonly covered by clothes, dirty and rude words is considered into taboo words and not commonly used in daily conversation, except for certain purposes. Third, the usage of euphemism, which is smoothing phrase. The usage of euphemism is needed to apply to avoid negative impression. Fourth, the usage of honorific words, which is expression of respecting to speak and greet other people.

Meanwhile, Brown and Levinson identify four basic strategies in Linguistic Politeness, which are 1. Bald on record strategy, 2. Positive politeness strategy, 3. Negative politeness strategy, and 4. Off-record strategy. Those four politeness strategy must be related to pragmatics parameter (Wijana, 1996, pp. 64-65). In Brown and Levinson politeness model (1987), there are three parameter or determinant scale of high or low the politeness level of act. Those three scales are determined contextually, social, and cultural which is completely consist of these scales: 1 . Social distance ratings scale between speaker and hearer is mostly determined by different parameter such $\mathrm{s}$ ages, sex, socio-cultural background. 2. Speaker and hearer relative power or usually called as power rating is based on asymmetry position between speaker and hearer. 3. Rank scale of speech act or usually called as rank rating or the degree of imposition associated with the required expenditure of goods or services based on the relative position of one speech act with other speech act. Sasangka (2004) explains pragmatically, the selection of unggah-ungguh form of Javanese language based on the situation factors(formal and informal, formal or informal) and social factor such as closeness, similarity and differences of speaker social status which creates symmetryasymmetry, close-not close, and mixture both of them.

In this research, politeness principal that is used refers to politeness principal proposed by Leech (1986), which are

1. First, applying politeness principal in language. This principal is marked by maximizing pleasure or respect, compliment and sympathy toward other people and minimizing those things toward themselves.

Example:

- Pancen enak tenan masakanmu, mantep rasane!

- Derek bingah inggih bu, putranipun sampun lulus kanti nilai ingkang sae.

2. Second, avoidance of the usage of taboo words. In most society, the words refers to something disgusting/dirty and rude includes taboo words and uncommonly used in daily communication.

Example:

- Nyuwun sewu, Ibu nembe wonten wingking. Panjenengan kapureh neggo sekedap.

3. Third, the usage of euphemism, which is smoothing phrase. The usage of euphemism is needed to apply to avoid negative impression.

Example:

- Bu Endang meniko sampun mboten permono makanipun mboten saged ningali tebih

4. Fourth, the usage of honorific words which is respecting phrase to speak and to greet other people. Example:

- Badhe tindak menopo Pakdhe?

\section{B. Language Impoliteness in Javanese Language Speech Act}

Culpeper (1996) in Wijayanto (2014) develops impoliteness strategy concept which are,

1. bald on record impoliteness. In this strategy, impoliteness happens because the speaker intentionally eager to corporate with the hearer or speaker does not want to keep the good relationship with the hearer.

Example: 
wegah aku nek kon ngancani Pak Karjo wong gaweyane mblenjani janji.

2. positive impoliteness. The acts that are considered into positive politeness are ignoring others, arguing, showing indifference / inadequacy to others, using inappropriate nicknames to the hearer, and using the taboo words.

Example:

Hei Dab, minggat kono.

3. negative impoliteness. In this negative impoliteness includes scaring, mocking and blaming hearer. Contoh: Kowe saiki lagi ngerti akibate to, ket ndisik tak kandhani ora nggugu sih.

4. mock politeness is apparent politeness strategy or pretending. Contoh: sakjane aku emoh dijak Bu Yuni mulih bareng lehku gelem kae mung mesakke nek ora duwe konco mulih.

5. withhold politeness is impoliteness because there is negligence or deliberation of speaker who does not use politeness that should be needed such as when helping, they do not say thank you or when borrowing other person's stuff, they do not ask for permission first. They do not want to answer greeting and etc. Contoh: masakanmu wingi enak tenan lo, mantep rasane.

Besides, in Javanese language, there is impoliteness that is caused by several things as follows,

1. The usage of inappropriate lexicon with the level of speech act,

Example:

Monggo ngrumiyini, kulo badhe dahar rumiyin. Penggunaan frase badhe dahar tidak tepat dan dianggap tidak/kurang santun dalam bahasa Jawa karena dalam konteks penggunaan bahasa Jawa tidak dibenarkan meninggikan status dirinya. Yang benar adalah Monggo ngrumiyini, kulo badhe nedho rumiyin.

2. The usage of rude word is considered also as impolite in Javanese language, for example: seseorang yang mengatakan temannya yang tidak suka berada di rumah dalam jangka waktu lama dengan perkataan kowe ki gaweyane mung kluyuran wae. Dalam bahasa Jawa kata kluyuran bermakna suka pergi meninggalkan rumah yang tidak sopan untuk diucapkan. Kalimat yang benar seharusnya kowe ki senengane lungo terus ora nate neng omah.

3. Socio-cultural can be the cause of impoliteness in using Javanese language, for example: in Javanese language, it is known word njangkar, which is pronouncing someone's name without greeting words such as Pak (sir), Bu (ma'am), Mas (brother), $M b a$ (sister), or Dik (little brother or sister). In the socio-cultural context, njangkar is considered into impoliteness.

Example: Sri, kowe mau digoleki Ibu.

kalimat tersebut dianggap tidak santun apabila diucapkan oleh seorang adik kepada kakaknya. Seharusnya kalimat yang santun adalah Mbak Sri, sampeyan mou dipadhosi Ibu. Moreover, in Javanese cultural context, it is known nglulu phrase. In pragmatic discourse, that speech act is called as indirect speech act or not literal. The meaning of indirect speech act is the speech act that is produced using modus and the meaning of the sentence is inappropriate with the intended meaning of the speaker. In Javanese society, indirect not literal speech act is called as nglulu. Nglulu in javanese socio-cultural context is considered as impolite.

Example: Monggo Jengayu dhaharanipun sampun Ibu cepakaken.

Tuturan tersebut dianggap tidak santun karena tidak seharusnya seorang ibu berbicara menggunakan krama alus kepada anaknya. Yang benar adalah $i k i$ nduk maeme wes Ibu gaweke. Ibu tersebut menggunakan bahasa krama alus kepada anaknya karena ibu tersebut merasa keberatan memasakkan makanan untuk anaknya. That is called nglulu in Javanese language context. Impoliteness in the usage of Javanese language in Javanese phrase is called as murang tata, degsura, and nerak suba sita.

\section{CONCLUSION}

In Javanese Linguistic Politeness, speech is considered as polite if the speech is appropriate with the correct level of speech. In addition, polite speech act is a speech that is done by the speaker to respect the hearer. In Javanese language concept, someone who can use the level of speech act correctly has high level of politeness in their behavior. This happens because there is positive correlation between speech act with behavior. More polite someone in speaking, the more polite the behavior. The usage of Javanese speech act level must be preserved so that Javanese young generation has politeness in speaking and in behavior, can keep someone's feeling, and control themselves and be sensitive toward environment which in Javanese cultural concept is called as empan papan.

\section{References}

Brown, P. \& Levinson, S.C. (1987). Politeness Some Universal in Language Usage. New York: Cambridge University Press.

Djajasudarma, T. F. (1993). Metode linguistik : Ancangan Metode Penelitian dan Kajian. Bandung: Eresco. 
Fathurohman, R. (2013). "Wujud Kesantunan Berbahasa sebagai Profesionalisme Guru di Tingkat Sekolah Dasar dalam Berkomunikasi melalui Media Short Message Service: Kajian Pragmatik". Prosiding Seminar Nasional 30 Maret 2013 Peranan Guru Profesional dan Berkarakter dalam Pembangunan Sumber Daya Manusiadi Era Global.

Leech, G. 1993. Prinsip-prinsip Pragmatik. Jakarta: UIPRESS.

Mahsun. (2005). Metode penelitian bahasa. Yogyakarta: Duta Wacana University Press.

Poedjosoedarmo, S. (1979). Tingkat Tutur Bahasa Jawa. Jakarta: Pusat Pembinaan dan Pengembangan Bahasa. Departemen Pendidikan dan Kebudayaan.

Sasangka, S. S. T. W.2004. Unggah ngguh bahasa Jawa. Jakarta: Yayasan Paramalingua.

Sudaryanto. (1993). Beberapa Catatan tentang Kata Halus dan Bentuk Krama dalam Bahasa Jawa.www.linguistik-indonesia.org.

Sudaryanto. (1993). Metode dan aneka teknik analisis bahasa. Yogyakarta: Duta Wacana University Press.

Wijayanto, A. (2014). "Ketidaksantunan Berbahasa: Penggunaan Bahasa Kekerasan di Sinetron Bertema Kehidupan Remaja". Prosiding Seminar Nasional Ketidaksantunan Berbahasa dan Dampaknya dalam Pembentukan Karakter. Surakarta, 25 Januari 2014.

Wijana, I D. P. (1996). Dasar-dasar Pragmatik. Yogyakarta: Andi Offset. 